\title{
Isolation of Polysomes from Nostoc sp. MAC and Translation of Messenger RNA in a Heterologous Cell-free System
}

\author{
By MANJU GUPTA† AND N. G. CARR* \\ Department of Biochemistry, University of Liverpool, Liverpool L69 3BX, U.K.
}

(Received 18 October 1982)

\begin{abstract}
A method has been established which isolates polysomes from the lysozyme/EDTA-shocked cyanobacterium, Nostoc sp. MAC. In a typical preparation the total recovery of RNA as polysomes was $83 \%$, in which $77 \%$ of the polysome fraction was present at sizes $>5$-mers and $23 \%$ as 2-4-mers. Messenger RNA isolated from such a preparation of polysomes produced a 10 -fold stimulation in the incorporation of $\left[{ }^{35} \mathrm{~S}\right]$ methionine into polypeptides by a cell-free system of Escherichia coli. The in vitro-synthesized polypeptides were analysed on an SDSpolyacrylamide gradient gel together with in vivo-labelled proteins of Nostoc sp. MAC: seven polypeptides co-migrated with the in vivo-synthesized products. This is the first report of the expression of cyanobacterial messenger RNA in a heterologous cell-free system from E. coli; the efficiency of the system is discussed.
\end{abstract}

\section{INTRODUCTION}

In the first report of the in vitro translation of cyanobacterial mRNA, $\left[{ }^{14} \mathrm{C}\right]$ leucine was shown to be incorporated into an insoluble fraction by crude extracts of Anacystis nidulans (Bazin, 1970). Leach \& Carr (1974) examined the in vitro protein synthesis in extracts of Anabaena variabilis and estimated the half-life of the $\mathrm{mRNA}$ to be $12 \mathrm{~min}$. In both these reports the mRNA was translated by cell-free preparations of its own organism and the products were not characterized with respect to size. Careful separation procedures can lead to the isolation of polysomes in which a number of ribosomes are attached to the same mRNA molecule. Polysomes have been successfully used as a means of separating mRNA in a functionally intact form from a wide range of organisms, including higher plants, yeast and microalgae (Dunham \& Thurston, 1980; Hall, 1979; Kraig \& Haber, 1980; Turner et al., 1981). Many cyanobacteria change the amount and identity of their phycobiliprotein light-harvesting pigments in response to both qualitative and quantitative change in incident light. The total amounts of such pigments are, generally, inversely proportional to light intensity and some species show chromatic adaptation, in which different phycobiliproteins are synthesized so as to maximize the harvesting of the light available. The phycobiliproteins comprise a major proportion, up to $50 \%$, of the total soluble protein of exponentially growing cyanobacteria, and therefore alteration in their rates of synthesis involves considerable changes in gene expression (see Glazer, 1976; Doolittle, 1979; Cohen-Bazire \& Bryant, 1982). The understanding of the control of phycobiliprotein synthesis will be aided by characterization of the mRNAs involved. This communication describes the isolation, and expression in a heterologous system, of mRNA from polysomes prepared from Nostoc sp. MAC, a cyanobacterium which chromatically adapts to green or red light.

† Present address: Max-Planck-Institut für Züchtungforschung, D-5000 Köln-30, Federal Republic of Germany.

Abbreviations: DOC, sodium deoxycholate; DTT, dithiothreitol; LDS, lithium dodecyl sulphate. 


\section{METHODS}

Culture and growth. Nostoc sp. MAC (obtained from Dr A. J. Smith and deposited as PCC 8009, Institut Pasteur, Paris, France) was cultured at $37^{\circ} \mathrm{C}$ in medium $\mathrm{C}$ of $\mathrm{Kratz} \&$ Myers (1955) supplemented with $0 \cdot 1 \%(\mathrm{w} / \mathrm{v})$ sodium bicarbonate and gassed with air $/ \mathrm{CO}_{2}(95: 5, \mathrm{v} / \mathrm{v})$ at a light intensity of $75 \mu \mathrm{E} \mathrm{m} \mathrm{m}^{-2} \mathrm{~s}^{-1} ; 2$-litre or 10 -litre culture volumes were employed for polysome isolation.

Harvesting. When the culture density had reached approximately $0.25 \mathrm{~g}$ wet wt $\mathrm{l}^{-1}$, chloramphenicol ( $\left.3 \mathrm{mg} \mathrm{l}^{-1}\right)$ was added 10-15 min prior to harvesting. This prevented the 'run-off' of the ribosomes from mRNA during harvesting and cell lysis, and maximized polysome yield. The culture was cooled by addition of an equal volume of crushed ice and organisms were collected on filter paper in a Buchner funnel under gentle vacuum. The whole process took 4-5 min for 2-litre cultures.

Polysome isolation. The basic procedure was modified from Godson (1967). In principle, a precise EDTA/lysozyme shock was given to the cells followed by lysis with neutral detergents in the presence of magnesium ions. Every step was carried out at $0-4{ }^{\circ} \mathrm{C}$ using cold buffers and sterile glassware to minimize RNAase activity.

Organisms $(0.50 \mathrm{~g})$ were resuspended in $2.0 \mathrm{ml} 25 \%(\mathrm{w} / \mathrm{v})$ sucrose in $10 \mathrm{mM}$-Tris $/ \mathrm{HCl}, 12 \mathrm{~mm}$-dithiothreitol (DTT), pH $8 \cdot 1$, and $0.5 \mathrm{ml}$ EDTA/lysozyme (lysozyme at $10 \mathrm{mg} \mathrm{ml}^{-1}$ in $250 \mathrm{~mm}$-Tris/ $\mathrm{HCl}$, pH 8.1 plus an equal volume of $8 \mathrm{~mm}$-EDTA) was added and the suspension left on ice with occasional gentle swirling. After $10 \mathrm{~min}$, $2.5 \mathrm{ml} \mathrm{lytic}$ mixture $\left[0.5 \mathrm{ml}\right.$ each of $300 \mathrm{mM}-\mathrm{MgCl}_{2}, 10 \%(\mathrm{w} / \mathrm{v})$ sodium deoxycholate (DOC), $10 \%(\mathrm{w} / \mathrm{v}$ ) Brij 35 and $10 \%(\mathrm{v} / \mathrm{v})$ Triton X-100 each dissolved in $100 \mathrm{~mm}$-Tris/HCl, $\mathrm{pH} 8.1$ and $200 \mathrm{~mm}$-EGTA] was added. The final concentrations of reagents at the time of lysis were: $46 \mathrm{~mm}-\mathrm{Tris} / \mathrm{HCl}, \mathrm{pH} 8 \cdot 1,10 \%$ sucrose, $0.5 \mathrm{mg}$ lysozyme $\mathrm{ml}^{-1}$, $0.4 \mathrm{~mm}$-EDTA, $1 \%$ DOC, $1 \%$ Triton X-100, $1 \%$ Brij 35, $20 \mathrm{~mm}$-EGTA and $30 \mathrm{~mm}-\mathrm{MgCl}_{2}$. The suspension was moved on and off the ice alternately for $5 \mathrm{~min}$, thus raising the temperature of the suspension and increasing lysis. Lysis was detected microscopically $10 \mathrm{~min}$ after the addition of lytic mixture, but $20 \mathrm{~min}$ more were required for its completion, when $90-95 \%$ of the cells were broken. At this stage, $0.55 \mathrm{ml} 4 \mathrm{M}-\mathrm{KCl}$ in $200 \mathrm{mM}-\mathrm{Tris} / \mathrm{HCl}, \mathrm{pH} 8 \cdot 1$ was added and cells and cell-debris were removed by centrifugation at $27000 \mathrm{~g}$ for $25 \mathrm{~min}$. The supernatant was layered on to $3 \mathrm{ml} 60 \%$ sucrose made up in $400 \mathrm{~mm}-\mathrm{KCl}, 15 \mathrm{mM}-\mathrm{MgCl}_{2}, 5 \mathrm{~mm}$-EGTA, $5 \mathrm{~mm}$-DTT and $40 \mathrm{~mm}$ Tris/ $\mathrm{HCl}, \mathrm{pH} 8.0$ (polysome buffer) and centrifuged at $200000 \mathrm{~g}$ for $3 \mathrm{~h}$. The supernatant was carefully removed with a Pasteur pipette and the sides of the tubes were washed with distilled water and carefully wiped. The opalescent polysome pellet was resuspended as required.

Test for polysome integrity. The polysome pellet was resuspended in $300 \mu \mathrm{l}$ polysome buffer containing $0 \cdot 2 \mathrm{M}-$ sucrose. About 5.0 $A_{260}$ units of polysomes were put on each $16 \mathrm{ml}$ sucrose gradient formed by layering $2,4,4$ and $6 \mathrm{ml}$ of $15,25,35$ and $45 \%$ solutions, respectively, of sucrose in buffer $\left(40 \mathrm{~mm}\right.$-Tris/ $\mathrm{HCl}, 10 \mathrm{mM}-\mathrm{MgCl}_{2}, 60 \mathrm{~mm}-$ $\mathrm{KCl}, 5 \mathrm{~mm}-\mathrm{DTT}, \mathrm{pH} 8.0$ ) and centrifuged at $95000 \mathrm{~g}$ for $105 \mathrm{~min}$. The profile of the polysome distribution, measured at $A_{254}$, was analysed by piercing the bottom of the tube with an ISCO density gradient fractionator (model 183) and displacing the contents upwards into a $2 \mathrm{~mm}$ light path of a ISCO model UA-4 absorbance monitor. Optical density was later multiplied by 5 to give unit absorbance in a $1 \mathrm{~cm}$ light path.

Isolation of polysomal RNA. Polysome pellets were resuspended in buffer $\left(10 \mathrm{~A}_{260}\right.$ units $\left.\mathrm{ml}^{-1}\right)$ containing $10 \mathrm{mM}$ Tris $/ \mathrm{HCl}, 100 \mathrm{~mm}-\mathrm{LiCl}, 1 \mathrm{~mm}-\mathrm{EDTA}$ and $0.5 \%(\mathrm{w} / \mathrm{v})$ lithium dodecyl sulphate (LDS), $\mathrm{pH} 7.4$ and deproteinized two or three times with an equal volume of redistilled phenol/chloroform $(1: 1, \mathrm{v} / \mathrm{v})$. RNA was precipitated from the aqueous phase with $2 \mathrm{vol}$. redistilled ethanol in the presence of $0.1 \mathrm{vol} .2 .4 \mathrm{M}$-ammonium acetate at $-20^{\circ} \mathrm{C}$. After $2 \mathrm{~h}$, the RNA precipitate was collected by centrifugation at $50000 \mathrm{~g}$ for $15 \mathrm{~min}$ and dissolved in $1 \mathrm{ml} 10 \mathrm{~mm}$ Tris/ $\mathrm{HCl}$ containing $150 \mathrm{~mm}$-lithium acetate, $2 \mathrm{~mm}$-EDTA and $0.5 \% \mathrm{LDS}$ at $\mathrm{pH} 6.0$. RNA was reprecipitated by the addition of $2 \mathrm{vol}$. ethanol, held at $-20{ }^{\circ} \mathrm{C}$ for $2 \mathrm{~h}$ and centrifuged. The precipitate was washed twice with $70 \%$ $(\mathrm{v} / \mathrm{v})$ ethanol containing $50 \mathrm{~mm}-\mathrm{KCl}$ and put under vacuum for $5 \mathrm{~min}$ to evaporate the remaining ethanol. When required for use in in vitro translation systems, polysomal RNA was dissolved in buffer $(10 \mathrm{mM}-\mathrm{Tris} / \mathrm{HCl}, 30 \mathrm{mM}$ $\mathrm{NH}_{4} \mathrm{Cl}, 10 \mathrm{mM}-\mathrm{MgCl}_{2}, 6 \mathrm{~mm}-\beta$-mercaptoethanol, $\left.\mathrm{pH} 8.5\right)$ and used immediately; storage in liquid nitrogen for several days did not reduce messenger activity. All operations were performed at $4{ }^{\circ} \mathrm{C}$ to avoid degradation of polysomal RNA, which was shown to occur at room temperature.

Isolation of $m R N A$ by stripping from polysomes. Polysomes isolated from 10-litre cultures were resuspended in the buffer containing $20 \mathrm{mM}$-Tris/HCl, $20 \mathrm{mM}$-EDTA, $100 \mathrm{mM}$ - LiCl and $10 \mathrm{~mm}$-DTT, pH $8.0\left(25 A_{260}\right.$ units $^{-1}$ ), left on ice for $1 \mathrm{~h}$ with occasional swirling to allow complete separation of mRNA from ribosomes, and then centrifuged at $200000 \mathrm{~g}$ for $2 \mathrm{~h}$ to pellet ribosomes. The supernatant containing mRNA was deproteinized and first made ready for in vitro.translation as described above for polysomal RNA except that RNA precipitation was carried out overnight at $-20^{\circ} \mathrm{C}$, followed by centrifugation at $100000 \mathrm{~g}$ for $30 \mathrm{~min}$.

Preparation of cell-free extracts for in vitro synthesis. Escherichia coli strain PR7, which is a mutant lacking both RNAase I and polynucleotide phosphorylase, was used for the preparation of ribosomal and supernatant fractions for in vitro protein synthesis. It was grown aerobically in yeast/tryptone medium ( $16 \mathrm{~g}$ Bactotryptone, $10 \mathrm{~g}$ yeast extract and $5 \mathrm{~g} \mathrm{NaCl}^{-1}$ ) at $37^{\circ} \mathrm{C}$ to an $A_{550}$ of 2 , cooled with equal volume of ice, harvested and used immediately to purify the different fractions of the protein-synthesizing apparatus. Ribosomes were isolated from 
a pre-incubated S30 extract followed by high-speed centrifugation according to Crawford \& Gesteland (1973). Crude initiation factors were extracted from ribosomes after treatment with buffered $1 \mathrm{M}-\mathrm{NH}_{4} \mathrm{Cl}$; the ribosomes were centrifuged and the supernatant was precipitated with ammonium sulphate. Fraction 'S100 DE' was the high-speed supernatant of cell-free extract after passage through a DEAE-cellulose column to free it of low molecular weight proteins and RNA. Both these fractions were purified as described by Traub et al. (1971). All three fractions were stored as small samples in liquid nitrogen. Transfer RNA was purified from total RNA of $E$. coli as described by Leach \& Carr (1974).

In vitro protein synthesis. The reaction mixture (final volume $25 \mu \mathrm{l}$ ) contained, in $5.4 \mu \mathrm{l}$ : Tris/acetate, $50 \mathrm{~mm}$; $\mathrm{NH}_{4} \mathrm{Cl}, 75 \mathrm{~mm}$; magnesium acetate, $11.2 \mathrm{~mm}$; ATP, $3 \mathrm{mM}$; GTP, $0.5 \mathrm{~mm}$; phosphoenolpyruvate, $5 \mathrm{~mm}$; pyruvate kinase, $50 \mu \mathrm{g} \mathrm{ml}^{-1}$; DTT, $2 \mathrm{mM} ; 19 \mathrm{~L}$-amino acids, $0.25 \mathrm{mM}$; ${ }^{35}$ S $]$ methionine $\left(840-1445 \mathrm{Ci} \mathrm{mmol}^{-1}\right)$, $10 \mu \mathrm{Ci}(370 \mathrm{kBq})$. The cell-free fractions comprised: ribosomes $\left(18 \mathrm{mg} \mathrm{ml}^{-1}\right), 7 \cdot 5 \mu \mathrm{l}$; crude initiation factors (13.44 $A_{280}$ units), $2 \mu \mathrm{l} ; \mathrm{S} 100 \mathrm{DE}\left(26 A_{260}\right.$ units), $2 \mu \mathrm{l} ; \mathrm{tRNA}\left(4 \mathrm{mg} \mathrm{ml}^{-1}\right), 0.625 \mu \mathrm{l}$; m RA from Nostoc sp. MAC and distilled water made up to the final volume. Each component of the reaction mixture and cell-free fractions was tested individually in different concentrations to maximize protein synthesis. The reaction was carried out at $37^{\circ} \mathrm{C}$ for $30 \mathrm{~min}$ and stopped by addition of $12 \mathrm{~mm}$-methionine $(5 \mu \mathrm{l})$ and $6 \mathrm{M}-\mathrm{NaOH}(15 \mu \mathrm{l})$ with further incubation for $2 \mathrm{~min}$ at $37^{\circ} \mathrm{C}$ to hydrolyse RNA. Samples were chilled on ice and the proteins precipitated by the addition of $150 \mu 110 \%(\mathrm{w} / \mathrm{v}) \mathrm{TCA}$, washed once with ethanol/ether $(1: 1, \mathrm{v} / \mathrm{v})$ and once with ether and then dried. The precipitate was dissolved in $50 \mu \mathrm{l}$ sample buffer $[60 \mathrm{~mm}$-Tris $/ \mathrm{HCl}, 10 \%(\mathrm{v} / \mathrm{v})$ glycerol, $5 \mathrm{~mm}-\mathrm{DTT}, 1 \%(\mathrm{w} / \mathrm{v})$ SDS and $0.001 \%$ bromophenol blue) and heated for $10 \mathrm{~min}$ at $100{ }^{\circ} \mathrm{C}$, and triplicate samples $(3 \mu \mathrm{l})$ were placed in Aquasol for radioactive counting. The remainder was saved for gel electrophoresis.

Analytical polyacrylamide gel electrophoresis. The in vitro translation product was fractioned on SDSpolyacrylamide gels using a discontinuous buffer system (Laemmli, 1970). A 12-22\% gradient of polyacrylamide slab gel $(15.5 \times 15 \times 0.1 \mathrm{~cm})$ containing $0.18(\mathrm{w} / \mathrm{v})$ bisacrylamide and $0.1 \%(\mathrm{w} / \mathrm{v})$ SDS was run initially at $10 \mathrm{~mA}$ for $1 \mathrm{~h}$, and then at $20 \mathrm{~mA}$ for $5 \mathrm{~h}$, along with marker proteins. The lanes corresponding to the protein markers were separated from the rest of the gel, stained overnight at room temperature with $0 \cdot 1 \%(\mathrm{w} / \mathrm{v})$ kenacid blue $\mathrm{R}$ in $45.2 \%(\mathrm{v} / \mathrm{v})$ methanol and $9.6 \%(\mathrm{v} / \mathrm{v})$ glacial acetic acid and destained with $7 \%$ acetic acid and $20 \%$ methanol; the remainder of the gel was processed for fluorography (Bonner \& Laskey, 1974). After impregnation with PPO, the gel was immersed for $1 \mathrm{~h}$ in $1 \%$ glycerol and dried overnight between two sheets of cellophane paper. The gel was fluorographed in contact with Ilford X-ray film at $-70^{\circ} \mathrm{C}$.

In vivo labelling of proteins. ${ }^{35} \mathrm{SO}_{4}^{2-}(2 \mathrm{mCi}$ per $150 \mathrm{ml})$ was added to a suspension $\left(1.2 \mathrm{mg}\right.$ wet wt $\left.\mathrm{ml}^{-1}\right)$ of exponentially growing Nostoc sp. MAC and the suspension was incubated for $4 \mathrm{~h}$ under growth conditions. The culture was then cooled on ice, harvested and washed three times with $100 \mathrm{~mm}-\mathrm{Tris} / \mathrm{HCl}, \mathrm{pH} 7 \cdot 2$, sonicated in the same buffer and centrifuged at $10000 \mathrm{~g}$ for $10 \mathrm{~min}$ at $4{ }^{\circ} \mathrm{C}$. An equal volume of $10 \%$ TCA was added to supernatant, which was then left on ice for $1 \mathrm{~h}$. The precipitate was centrifuged, washed three times with $5 \%$ TCA, twice with acetone and once with ether, and then dried. The residue was dissolved in the sample buffer as used for the in vitro product and heated for $10 \mathrm{~min}$ in a boiling water bath, and samples were electrophoresed.

Chemicals. Sources were as follows: ATP, GTP, EGTA, Brij 35, lysozyme and phosphoenolpyruvate from Sigma; sucrose (density gradient grade) from Schwarz/Mann; DNAase (RNAase-free) from Millipore; DTT and pyruvate kinase from Boehringer-Mannheim; ${ }^{35}$ S]methionine and $\mathrm{Na}_{2}{ }^{35} \mathrm{SO}_{4}$ from Amersham; Aquasol and PPO from New England Nuclear; DEAE-cellulose from Whatman; electrophoresis reagents from Bio-Rad; Bactotryptone and yeast extract from Difco. All other chemicals used were of high purity grade and purchased from BDH.

\section{RESULTS}

Although the cell wall of Nostoc sp. MAC was more resistant to lysozyme treatment than those of many bacteria, a good yield of polysomes was obtained after a brief lysozyme shock followed by cell lysis. Under standard conditions of lysis, about 30-35 $A_{260}$ units of polysomes were routinely obtained per $\mathrm{g}$ broken cells. The ratio of $\boldsymbol{A}_{260}$ to $\boldsymbol{A}_{280}$ of the suspended isolated polysomes varied from 1.72 to 1.8 (mean 1.76), characteristic of undegraded polysomes. The total time required to lyse $90-95 \%$ of a Nostoc $\mathrm{sp}$. MAC suspension was about $45 \mathrm{~min}$, which was considered reasonable and avoided lengthy steps of centrifugation.

A typical sedimentation profile of intact polysomes on a sucrose density gradient is shown in Fig. 1 (a). The concentrations of subunits and monosomes and polysomes were calculated by counting the areas below their respective peaks. Polysomes containing two or more ribosomes are subsequently referred to as 'mers' (Davies \& Larkins, 1972). The total recovery of the polysomes was $83 \%$, and only $10 \%$ was present as monosomes. A peak of polysomes present in the $>7$-mers region contributed $40 \%$ of the total polysomes, which was greater than the 


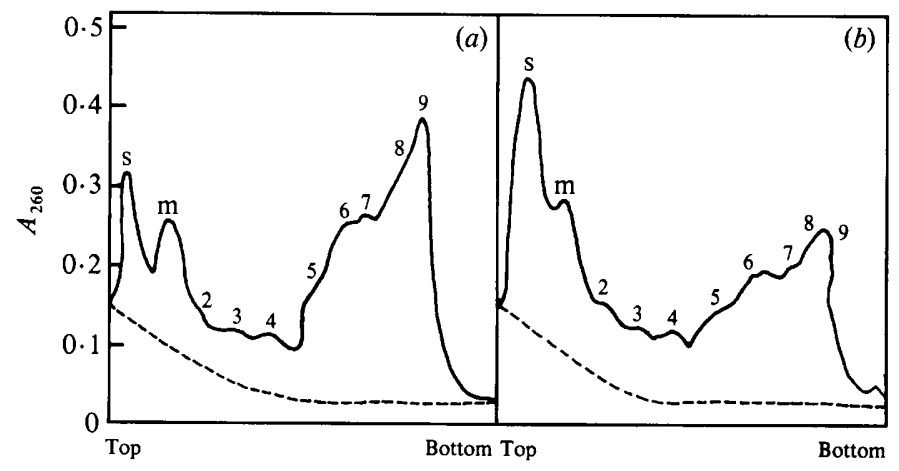

Fig. 1. Sucrose density gradient profiles of polysomes isolated from Nostoc sp. MAC under the conditions described in Methods. (a) Profile obtained after the addition of $20 \mathrm{~mm}$-EGTA into the lytic mixture. (b) Without EGTA addition, the lytic mixture being the same as in (a) except that $\mathrm{MgCl}_{2}$ was decreased to $10 \mathrm{mM}$ and DNAase (RNAase-free; $5 \mu \mathrm{g} \mathrm{ml}^{-1}$ ) was added. The dashed line represents the control in which buffer was put on top of the gradient. s, subunits; m, monosomes; peaks 2-9 represent polysomes.

percentage of polysomes present as $5-7$-mers $(37 \%)$ or $2-4$-mers $(23 \%)$. When EGTA was omitted from the lytic mixture and buffers, a slightly better yield of polysomes was obtained (35$40 A_{260}$ units per $\mathrm{g}$ broken cells) after addition of DNAase at the time of lysis. However, under these conditions the polysomes were comparatively more degraded, as indicated by the sucrose density gradient profile (Fig. $1 \mathrm{~b}$ ). Monosomes and subunits contributed $30 \%$ of the total yield, and the ratio of $>5$-mers to $<5$-mers was also low $(2 \cdot 8)$ when compared with the value from the lytic mixture containing EGTA.

A similar observation was made when chloramphenicol was omitted before harvesting, or when cells were incubated on ice after harvesting for $1 \mathrm{~h}$ or less prior to lysis without chloramphenicol addition. Under both conditions, degradation of polysomes was reflected in a high monosome peak. An attempt to lyse the cells in a higher concentration of Tris (100 mM) and salt $(\mathrm{KCl}, 200 \mathrm{mM})$, prolonged the lysis to $1 \mathrm{~h}$, though no significant effect on recovery of polysomes was observed. Therefore, cells were always lysed under optimal Tris concentration $(46 \mathrm{~mm})$ at $\mathrm{pH} 8 \cdot 1$. No inhibitor of ribonuclease activity was tested except DTT, and the temperature was kept between 0 and $4{ }^{\circ} \mathrm{C}$ unless stated.

The kinetics of $\left[{ }^{35} \mathrm{~S}\right]$ methionine incorporation into proteins by a cell-free system of $E$. coli directed by polysomal RNA from Nostoc sp. MAC as mRNA source is shown in Fig. 2. Amino acid incorporation was linear with increasing RNA concentration up to $25 \mu \mathrm{g}$ RNA per assay and then declined at concentrations above $35 \mu \mathrm{g}$ RNA per assay. This system gave threefold stimulation over the endogenous level. Different buffers, having various concentrations of Tris, salt and EDTA, were tested for their effects on the stripping of mRNA from ribosomal complexes (Table 1). Buffer 3, with $20 \mathrm{~mm}$-Tris/HCl pH 8.0, $20 \mathrm{~mm}$-EDTA, $100 \mathrm{~mm}-\mathrm{LiCl}$ and 10 mM-DTT, was most effective with respect to both mRNA release and amino acid incorporation into polypeptides per unit polysome. This procedure gave about $85 \%$ reduction in rRNA content from total polysomal RNA. Such RNA, when expressed in the in vitro system, resulted in the incorporation of ${ }^{35}$ S $]$ methionine into protein as a function of RNA concentration (Fig. 2). The incorporation was linear up to $100 \mu \mathrm{g}$ RNA per assay, giving a sixfold stimulation. Above this concentration a non-linear response was observed, yielding a 10fold stimulation of incorporation with $300 \mu \mathrm{g}$ RNA. The time course of amino acid incorporation in vitro reached a plateau after $30 \mathrm{~min}$. The effect of omitting different constituents from the standard reaction mixture was examined (Table 2). When fraction S100 DE was isolated from Nostoc sp. MAC using the same procedure as for $E$. coli and employed in the reaction mixture alone or in different combinations with E. coli S100 DE, no enhancement of polypeptide synthesis was observed; furthermore, omission of S100 DE reduced incorporation by only $50 \%$. Mercaptoethanol ( $4 \mathrm{mM}$ ) and reduced glutathione (10 $\mathrm{mM})$ 


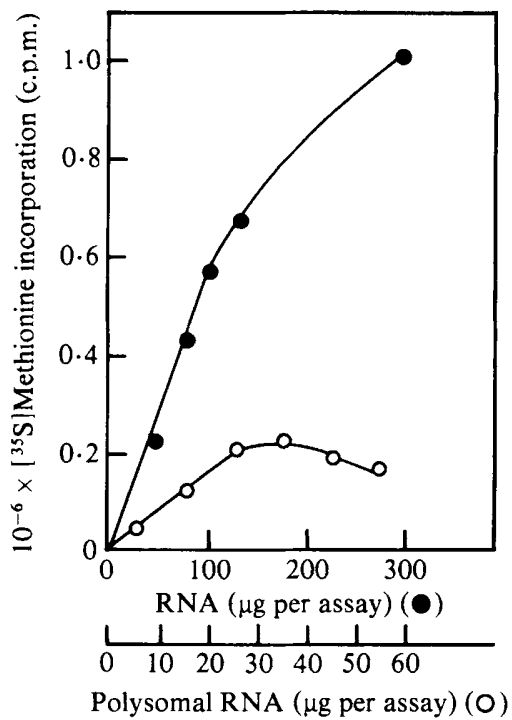

Fig. 2. Relationship between added Nostoc sp. MAC mRNA and incorporation of $\left[{ }^{35} \mathrm{~S}\right]$ methionine into polypeptides in a cell-free system of $E$. coli. , mRNA stripped from the ribosomal complex was used as RNA source as described in Methods; $O$, total polysomal RNA was used as RNA source.

Table 1. Effect of buffer composition on the release of $m R N A$ from ribosomes and its subsequent cell-free translation in an $E$. coli system

\begin{tabular}{|c|c|c|c|c|c|c|}
\hline \multirow[b]{2}{*}{ Buffer* } & \multicolumn{3}{|c|}{ Constituents (mM) } & \multirow{2}{*}{$\begin{array}{l}\text { Polysomes } \\
\left.\text { ( } A_{260} \text { units }\right)\end{array}$} & \multirow{2}{*}{$\begin{array}{l}\text { RNA released } \\
\text { ( } \mu \text { g per unit } \\
\text { polysomes) }\end{array}$} & \multirow{2}{*}{$\begin{array}{c}{\left[{ }^{35} \mathrm{~S}\right] \text { Methionine }} \\
\text { incorporation } \\
\text { (c.p.m. per } \mu \mathrm{g} \mathrm{RNA} \text { ) }\end{array}$} \\
\hline & Tris/HCl & EDTA & $\mathrm{LiCl}$ & & & \\
\hline 1 & 10 & 20 & 50 & 6.57 & 14.8 & $3.6 \times 10^{3}$ \\
\hline 2 & 20 & 10 & 100 & $7 \cdot 25$ & $12 \cdot 1$ & $2 \cdot 1 \times 10^{3}$ \\
\hline 3 & 20 & 20 & 100 & 5.63 & $13 \cdot 9$ & $6.1 \times 10^{3}$ \\
\hline 4 & 40 & 20 & 200 & $7 \cdot 71$ & $8 \cdot 5$ & $3.9 \times 10^{3}$ \\
\hline
\end{tabular}

Table 2. Incorporation of $\left[{ }^{35} S\right]$ methionine into proteins directed by Nostoc sp. MAC mRNA in an E. coli cell-free system

$\begin{array}{lc} & \begin{array}{c}\text { Relative } \\ \text { incorporation } \\ (\%)\end{array} \\ \text { Complete system } & 100^{*} \\ \text { - Ribosomes } & 7 \\ \text { - Initiation factors } & 40 \\ \text { - S100 DE } & 50 \\ \text { - mRNA } & 11 \\ \text { + RNAase }\left(50 \mu \mathrm{g} \mathrm{ml}^{-1}\right) & 10 \\ \text { - DTT } & 60 \\ \text { - tRNA } & 49 \\ \text { * } 100 \%=0.5 \times 10^{6} \text { c.p.m. }\end{array}$

in place of DTT inhibited the incorporation by $53 \%$ and $100 \%$, respectively. Crude S30 extract of $E$. coli, when used in place of purified ribosomes, initiation factors and S100 DE fractions, gave no incorporation of amino acids in polypeptides on addition of mRNA from Nostoc sp. MAC. The efficiency of the system was tested periodically using total polysomal RNA from E. coli. 


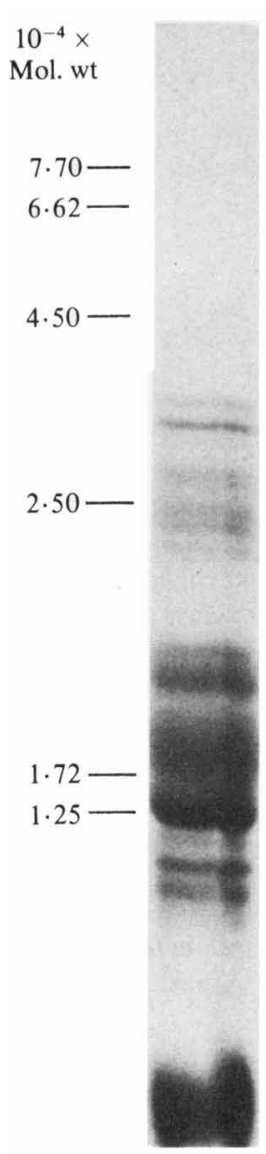

(a)

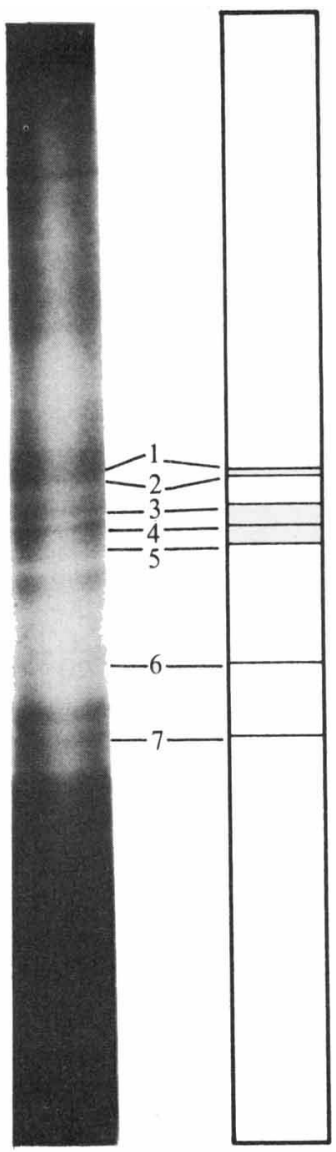

(b)

Fig. 3. Fluorogram showing analysis of (a) in vivo-labelled and $(b)$ in vitro-labelled polypeptide products on $12-22 \%$ SDS-polyacrylamide gels. Marked bands correspond to the seven polypeptides, labelled in vitro, which co-migrated with in vivo-labelled products. The diagram on the right indicates the positions of these bands.

The pattern of polypeptides obtained after in vivo labelling of proteins of Nostoc sp. MAC with ${ }^{35} \mathrm{SO}_{4}^{2-}$ was examined by analytical SDS-polyacrylamide gel electrophoresis. A number of polypeptide bands became distinct after a labelling period of $4 \mathrm{~h}$ and all of them showed molecular weights less than 35000 (Fig. $3 a$ ). The corresponding pattern of in vitro-labelled polypeptides on polyacrylamide gel is shown in Fig. 3(b). Seven polypeptides co-migrated with the in vivo-labelled proteins and fell in the molecular weight range 17500-30000; however, most of the synthesis resulted in small molecular weight polypeptides.

\section{DISCUSSION}

It has been emphasized that the ratio of higher $(>5$-mers) to lower $(<5$-mers) polymerized forms of polysomes is a more reliable criterion to judge polysome degradation resulting from RNAase activity than the ratio of polysomes to monosomes from a sucrose density gradient profile (Jackson \& Larkins, 1972). In our present findings, when EGTA was omitted from the lytic mixture, a lower value was obtained for both ratios, indicating polysome degradation to be a result of RNAase activity. Divalent cations are known to affect polysomes in two ways. Firstly, they cause aggregation of polysomes in cell-free extracts thereby reducing recovery of the polysomes (Jackson \& Larkins, 1972) and secondly, $\mathrm{Ca}^{2+}$ especially contributes to the 
degradation of polysomes by activating RNAases (Larkins \& Davies, 1973). EGTA is known to chelate divalent cations (Marhol \& Cheng, 1970); although we did not observe any improvement in the final yield of polysomes on EGTA addition, it is possible that it improved polysome recovery into higher polymers by inhibiting RNAase activity. Godson \& Sinsheimer (1967) reported a $10 \%$ lower yield of polysomes from $E$. coli when DNAase was omitted from the lytic mixture, the reason being that the entrapment of large polysomes by DNA molecules during low-speed centrifugation was increased. A $10-15 \%$ lower yield of polysomes in our experiments with EGTA (in which DNAase had no effect) may be due to the same phenomena.

Translation of total polysomal RNA in the cell-free system of $E$. coli produced only threefold stimulation of incorporation of labelled amino acid, and adding more RNA to the system produced inhibition in polypeptide synthesis. This may be due to the large amount of rRNA contaminating mRNA (Doolittle et al., 1979). There is no published report regarding the occurrence of poly(A)-containing mRNA in cyanobacteria, although recent experiments indicate that it may be present in Nostoc sp. MAC (Ownby et al., 1982). Therefore, in the experiments reported here deproteinization of polysomes was postponed until separation of mRNA from the ribosomal complex by chelation of $\mathrm{Mg}^{2+}$ ions, a method used for separation of mRNA in higher plants before the development of oligo-(dT) cellulose columns (Hall, 1979). This step reduced the level of $\mathrm{RNA}$ present and produced enrichment of mRNA, which yielded a 10 -fold stimulation in polypeptide synthesis by the cell-free system.

The results reported here demonstrate for the first time the expression of cyanobacterial mRNA in a heterologous cell-free system of $E$. coli. The similar electrophoretic mobility of in vivo- and in vitro-produced polypeptides coded for by Nostoc sp. MAC mRNA indicates that similar proteins are also synthesized in E. coli. The synthesis of small polypeptides in the E. coli cell-free system may be due either to the degradation of Nostoc sp. MAC mRNA in the system or to the premature switch-off in the polypeptide synthesis (Crawford \& Gesteland, 1973). Experiments are under way to identify the proteins synthesized in the cell-free system directed by mRNA isolated from polysomes prepared from Nostoc sp. MAC.

This work was supported by the Science and Engineering Research Council.

\section{REFERENCES}

BAZIN, M. J. (1970). Cell free polypeptide synthesis by crude extracts of the blue-green alga Anacystis nidulans. British Phycological Journal 5, 155-158.

BonNer, W. M. \& Laskey, R. A. (1974). A film detection method for tritium-labelled proteins and nucleic acids in polyacrylamide gels. European Journal of Biochemistry 46, 83-88.

Cohen-Bazire, G. \& Bryant, D. A. (1982). Phycobilisomes: composition and structure. In The Biology of Cyanobacteria, pp. 143-190. Edited by N. G. Carr \& B. A. Whitton. Oxford: Blackwell Scientific Publications.

Crawford, L. V. \& Gesteland, R. F. (1973). Synthesis of polyoma proteins in titro. Journal of Molecular Biology 74, 627-634.

Davies, E. \& Larkins, B. A. (1972). Polyribosomes from peas. II. Polyribosome metabolism during normal and hormone-induced growth. Plant Physiology 52. 339-345.

DoolitTLE, W. F. (1979). The cyanobacterial genome, its expression and the control of that expression. Advances in Microbial Physiology 20, 1-102.

Doolittle, W. F., Hofman, J. \& Sapienza, C. (1979). Analysis of transcription in Syechococcus 6301 using Southern hybridization. In Abstracts of the Third International Symposium on Photosynthetic Prokaryotes, Oxford, U.K., p. E18. Edited by J. M Nichols.
Dunham, S. M. \& Thurston, C. F. (1980). Messenger RNA for isocitrate lyase from Chlorella fusca var. vacuolata. Archives of Microbiology 128, 98-104.

Glazer, A. N. (1976). Phycocyanins: structure and function. Photochemical and Photobiological Reviews $1,71-115$.

Godson, G. N. (1967). A technique of rapid lysis for the preparation of Escherichia coli polyribosomes. Methods in Enzymology 12, 503-516.

Godson, G. N. \& Sinsheimer, B. (1967). Lysis of Escherichia coli with a neutral detergent. Biochimica et biophysica acta 149, 476-488.

HaLL, T. C. (1979). Plant messenger RNA. In Nucleic Acids in Plants, vol. 1, pp. 217-251. Edited by T. C. Hall \& J. W. Davies. Cleveland, Ohio: CRC Press.

JACKSON, A. O. \& LARKINS, B. A. (1972). Influence of ionic strength, $\mathrm{pH}$, and chelation of divalent metals on isolation of polyribosomes from tobacco leaves. Plant Physiology 57, 5-10.

KraIG, E. \& HABER, J. E. (1980). Messenger ribonucleic acid and protein metabolism during sporulation of Saccharomyces cerevisiae. Journal of Bacteriology 144 , 1098-1112.

Kratz, W. A. \& Myers, J. (1955). Nutrition and growth of several blue-green algae. American Journal of Botany 42, 282287.

LAEMMLI, U. K. (1970). Cleavage of structural proteins 
during the assembly of the head of the bacteriophage T4. Nature, London 227, 680-685.

Larkins, B. A. \& Davies, E. (1973). Polyribosomes from peas. III. Stimulation of polysome degradation by exogenous and endogenous calcium. Plant Physiology 52, 655-659.

LEACH, C. K. \& CARR, N. G. (1974). In vitro protein synthesis and measurement of the stability of messenger RNA in the blue-green alga, Anabaena variabilis. Journal of General Microbiology 81, 47-58.

MARHol, M. \& Cheng, K. L. (1970). Simple ionexchange separation of magnesium from calcium and other metal ions using ethyleneglycol-bis(2aminoethylether)tetraacetic acid as a complexing agent. Analytical Chemistry 42, 652-655.
OWnby, J. D., Crouch, D. C. \& CARR, N. G. (1982). Do cyanobacteria have polyadenylated mRNA? In $A b$ stracts of the Fourth International Symposium on Photosynthetic Prokaryotes, Bombannes, France, p. D2.

Traub, P., Mizushima, S., Lowry, C. V. \& Nomura, M. (1971). Reconstitution of ribosomes from subribosomal components. Methods in Enzymology 20, 391-407.

Turner, K. J., Bascomb, N. F., LynCh, J. C., Molin, W. T., Thurston, C. F. \& SChMidT, R. R. (1981). Evidence for messenger ribonucleic acid of an ammonium-inducible glutamate dehydrogenase and synthesis, covalent modification and degradation of enzyme subunits in uninduced Chlorella sorokiniana cells. Journal of Bacteriology 146, 578-589. 